\title{
実験住宅の床下における種々の粒子物理バリアの ヤマトシロアリ貫通阻止性能評価
}

\author{
簗瀬 佳之* ${ }^{1}$, 藤原 裕子* ${ }^{*}$, 藤井 義久*1, \\ 森拓郎*2, 吉村剛*3, 土居 修一*4
}

Evaluation of particulate materials as a physical barrier against penetration of Reticulitermes speratus under floor of experiment house

\author{
Yoshiyuki YAnASE* ${ }^{* 1}$, Yuko FujIwARA*1, Yoshihisa FujII*1, \\ Takuro MorI ${ }^{* 2}$, Tsuyoshi Yoshimura*3, Shuichi DoI ${ }^{* 4}$
}

In Japan, the damages by the subterranean termites (Coptotermes formosanus Shiraki and Reticulitermes speratus (Kolbe)) are the most important economically. Recently the more attention is paid to the less- or non-chemical methods for termite control. As a non-chemical treatment, physical barriers using particles such as gravels were investigated in terms of environmental safety, cost effectiveness, and duration of performance, and the physical barriers using some particles have been practically used in a few countries. In this study, penetration of $R$. speratus into physical barriers of seven different particulate materials such as pelletized stone powder, pelletized zeolite, crushed zeolite, calcite, crushed silica gel, silica gel beads, and glass beads were investigated under the floor of experiment house for seven years. Layers with particles of pelletized zeolite $(1.00$ to $4.00 \mathrm{~mm}$ in diameter), crushed zeolite (1.40 to $2.80 \mathrm{~mm})$, calcite $(1.40$ to $2.80 \mathrm{~mm})$, and crushed silica gel $(1.40$ to $2.80 \mathrm{~mm})$ prevented termites from passing through. On the other hand, for all of the layers with particles passed through by $R$. speratus, only the penetrations at the corner part of the particle laying area were observed, because of the gaps at the corner part where termites could pass through. It was considered that there were gaps at the corner part, since the wood stakes under the corner parts of the layer with particle was

\footnotetext{
* 1 京都大学大学院農学研究科

Graduate School of Agriculture, Kyoto University

* 2 広島大学大学院工学研究科

Graduate School of Engineering, Hiroshima University

* 3 京都大学生存圈研究所

Research Institute for Sustainable Humanosphere, Kyoto University

* 4 元筑波大学大学院生命環境科学研究科

Former Graduate School of Life and Environmental Sciences, University of Tsukuba

Corresponding author: Y. Yanase（yanase@h3news1.kais.kyoto-u.ac.jp）
} 
completely consumed by termites and the particles flowed into cavities.

Keywords ; physical barrier, particulate material, termite attack, penetration behavior, Reticulitermes speratus (Kolbe)

日本では地下シロアリのイエシロアリ Coptotermes formosanus Shiraki とヤマトシロア リReticulitermes speratus（Kolbe）の被害が経済的に最も重要である。近年，シロアリ防 除に対しては，レスケミカルまたはケミカルフリーな防除方法が注目されてきている。ケミ カルフリーな防除方法として, 砂利のような粒子を用いた物理バリアが環境への安全性，費 用効果，効果の持続性の点から検討され，種々の粒子材料を用いた物理バリアがいくつかの 国では実用化されてきた。本研究では, 実験住宅床下において, 石粉造粒材料, ゼオライト 造粒材料, ゼオライト破砕材料, カルサイト，シリカゲル破砕材料，シリカゲルビーズ，ガ ラスビーズの 7 種類の粒子材料を物理バリアとして用い，ヤマトシロアリに対して 7 年間に わたり貫通阻止性能を評価した。その結果，ゼオライト造粒材料（粒子径1.00 4.00 mm), ゼオライト破砕材料 (1.40 2.80mm), カルサイト (1.40 2.80mm), シリカゲル破砕材料 (1.40 〜 2.80mm）を用いた粒子層はヤマトシロアリの貫通を阻止した。一方，シロアリに貫通さ れた粒子層の全ては，粒子敷設領域の角部に生じた隙間からの貫通のみが観察された。粒子 層の角部直下に設置した餌杭がシロアリによって完全に消費され，それによってできた空洞 へ粒子が流出したために，角部の粒子層に隙間が生じシロアリが侵入できたと考えられる。

キーワード：物理バリア，粒子材料，シロアリ食害，貫通行動，ヤマトシロアリ（Reticulitermes speratus (Kolbe))

\section{1. 緒言}

近年，木造住宅における化学物質污染と，それ によって引き起こされるアレルギー疾患などの増 加が問題となり，化学物質に対する危険意識が消 費者の間で高まっている。シロアリ防除業界もそ のような動きに無関係でいることはできず，最近 ではレスケミカル（省薬施工）やケミカルフリー 工法という新しい防除技術の開発が期待されてい る。すでにアメリカなどでは, 次世代の防除法の 実験や実用化が進んでいる中，わが国でも日本の 風土，建築様式にあった防除技術の確立が必要に なってくる。薬剤を使わずにシロアリの侵入を阻 止する方法には, アメリカの $\mathrm{BTB}^{\circledR}$ (玄武岩の破 砕物) $)^{1)}$, オーストラリアの Granitgard ${ }^{\circledR}$ (花崗岩 の破砕物 $)^{2)}$ に代表される岩石破砕物や小石など の粒子を用いた物理バリア工法がある。これらは, 一定の粒子径範囲をもった粒子を層状に土猿表面 に敷設することで，地下からのシロアリの侵入を
防ぐ工法である。これまで, 様々な粒子を用いて, 地下シロアリの侵入に対する侵入阻止効果が検討 されてきたが, 砂や火山灰を用いた物理バリア層 では，1.2 1.7mm の粒子からなるバリア層が貫 通を阻止したという結果が最初に報告され ${ }^{3)}$, 粒 子を用いた物理バリアが化学防除の代替となりう る可能性が示された。また, 石英と化石サンゴか らなる砂粒を用いてガラス管内に物理バリア層を 作り, イエシロアリ Coptotermes formosanus Shiraki と欧州の地下シロアリである Reticulitermes flavipes（Kollar）について試験した結果, イエシロアリでは1.70 2.80mm, R. flavipes では 1.00 2.36mm の粒子層で貫通が阻止されること, 貫通が阻止された粒子径範囲よりも小さい粒子で は, 粒子がシロアリの口器で運搬され, 大きい粒子 ではシロアリによって粒子どうしの隙間を通り抜 けられ，バリア層が貫通されることがわかった ${ }^{4)} 。$ そのほか, 様々な粒子材料と地下シロアリ種との 組み合わせで, 物理バリア層の貫通阻止性能が検 
討されている ${ }^{5-9)}$ 。また, 物理バリアに最適な粒子 を選択するため, 粒子の形状や表面性状と貫通阻 止性能の関係についても検討した結果，粒子形状 が球形に近いほど粒子どうしが密に詰まって隙間 が小さくなり，また粒子の表面が滑らかなほど,小 さい粒子をシロアリが口器で挟んで運び出すのが 困難になることと，大きい粒子どうしの隙間を通 り抜ける際に粒子表面で滑って貫通が困難になる ことがわかり，表面のより滑らかな粒子材料が物 理バリアとして有効であることが報告された ${ }^{10}$ 。 さらに粉末ゼオライトから粒子材料を製造し，床 下環境改善に寄与する吸放湿性と，物理バリアと してのシロアリ貫通阻止性能を同時に有する粒子 材料の開発例 ${ }^{11)}$ も報告されている。

本研究では, 実験住宅の床下にヤマトシロアリ Reticulitermes speratus（Kolbe）を営巣させ, その床下土壤表面に実験室実験でシロアリ貫通阻 止性能が認められた粒子材料を敷設し， 7 年間の 物理バリアとしての貫通阻止性能を評価した。

\section{2. 実験方法}

\section{1 実験室における粒子材料選別試験}

シロアリ貫通阻止性能試験には，石粉造粒材料 (粒子径 $2.00 \sim 3.35 \mathrm{~mm}$ ), ゼオライト造粒材料 (1.40 ～2.36mm), ゼオライト破砕材料（1.40〜 $2.80 \mathrm{~mm})$, カルサイト $(1.40 \sim 2.80 \mathrm{~mm})$, シリカ ゲル破砕材料（1.40～2.80mm），シリカゲルビー ズ $(1.40 \sim 2.80 \mathrm{~mm})$, ガラスビーズ (1.70〜2.36mm) の 7 種類の粒子材料を用い，またコントロールと して砂壤土を用いた。なお, 筆者らの既往の研究10) より, 粒子の形状と表面性状を考慮して, 各粒子 材料の粒子径を決定した。

本実験は, 日本木材保存協会規格集 (2011年版 $)^{12)}$ に定められる「JWPAS-TS-(2)（2011）粒子によ る物理的防蟻層（粒子物理バリア）の性能基準及 び貫通阻止効力試験方法」の 4 。室内試験に準拠 して行ったが, 砂壤土の含水率調整と死虫率の記 録は行っておらず，試験体数は 3 本とした。試験 には，図1のような内径 $50 \mathrm{~mm}$ ，長さ $120 \mathrm{~mm}$ の 透明な円筒型ガラス製容器 2 本を，その底部付近 において内径 $20 \mathrm{~mm}$, 長さ $30 \mathrm{~mm}$ の透明ガラス管 で連結したU 字型ガラス製試験容器を用いた。 容器の片方の円筒に砂壤土を底辺から $40 \mathrm{~mm}$ の高

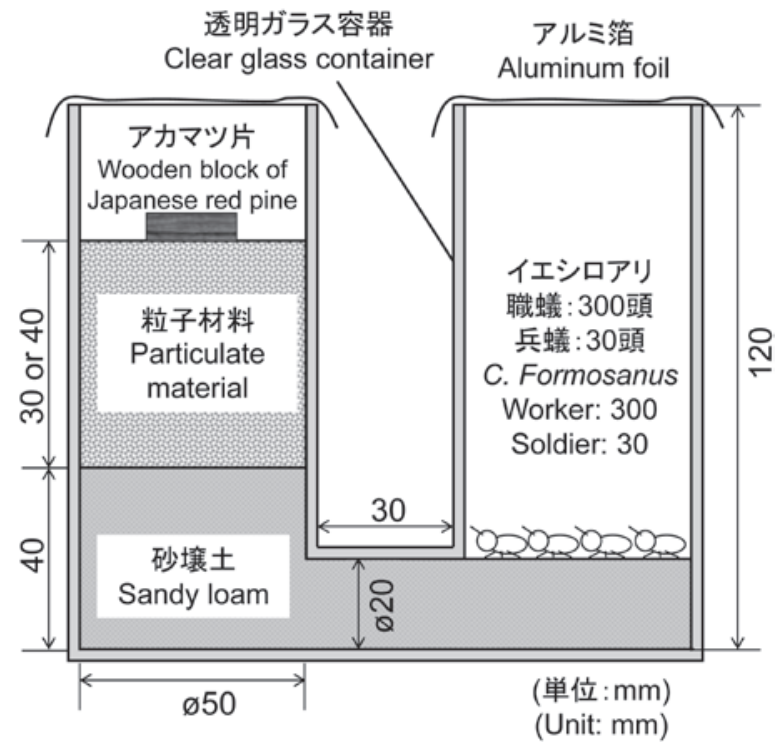

図1粒子層物理バリアのシロアリ貫通阻止性能試 験方法

Fig. 1 Termite penetration test of physical barrier using particulate material

さまで敷き詰め, もう一方の円筒には底辺から $20 \mathrm{~mm}$ の高さまで敷き詰め, それぞれの砂壤土に 水分を与えた。その際, 連結部のガラス管にも砂 壤土を詰めた。40mm の高さまで砂壤土を敷き詰 めた円筒に，さらに粒子材料または砂壤土（コン トロール）を任意の層厚さ（本実験では30または $40 \mathrm{~mm}$ ）で敷き詰め，その上に慨としてアカマッ (Pinus densiflora Sieb. et Zucc.) 試片を設置した。 粒子材料敷設側円筒と反対の円筒に，人工飼育室 $\left(28 \pm 2{ }^{\circ} \mathrm{C}\right.$ ，相対湿度 $80 \%$ 以上の暗室）で飼育さ れたイエシロアリの職蟻300頭と兵蟻30頭を投入 し，飭として水分を与えたろ紙も投入した。両円 筒の上端開口部をアルミ箔で密封しない程度に軽 く閉じたあと, 恒温恒湿器 $\left(28^{\circ} \mathrm{C}\right.$, 相対湿度 $75 \%$, $\mathrm{KCH}-1000$, 東京理科器械(侏) 内に設置し, 試験 期間は 3 週間とした。

\section{2 実験住宅の床下におけるヤマトシロアリ貫 通阻止性能試験}

シロアリ貫通阻止性能試験は京都大学生存圈研 究所 (京都府宇治市) のエコ住宅実験棟の床下で 行った。粒子材料を用いた物理バリアのシロアリ 貫通阻止性能試験では, 従来の化学薬剤の試験と は異なり，試験期間中にできるだけシロアリが死 滅することなく，常にシロアリによる粒子材料へ の貫通の可能性が認められる必要がある。したが 


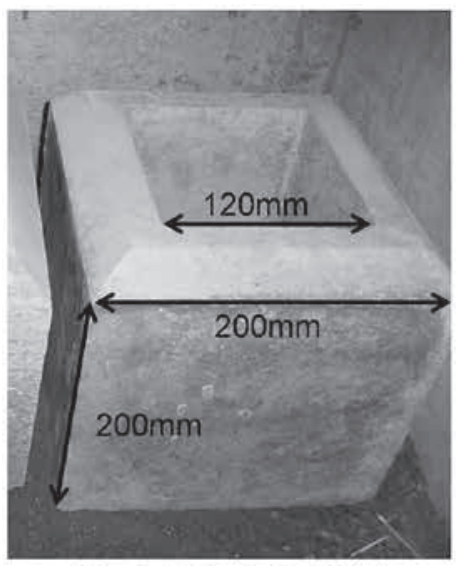

(a) コンクリート製会所枡 Concrete enclosure

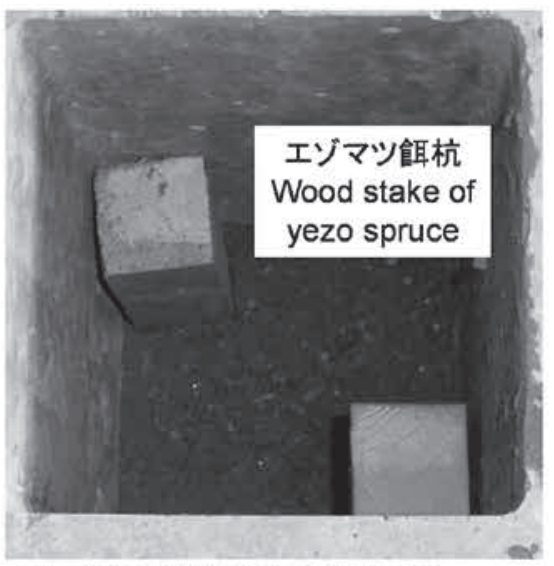

(b) エゾマツ餌杭2本の打ち込み Two wood stakes of yezo spruce

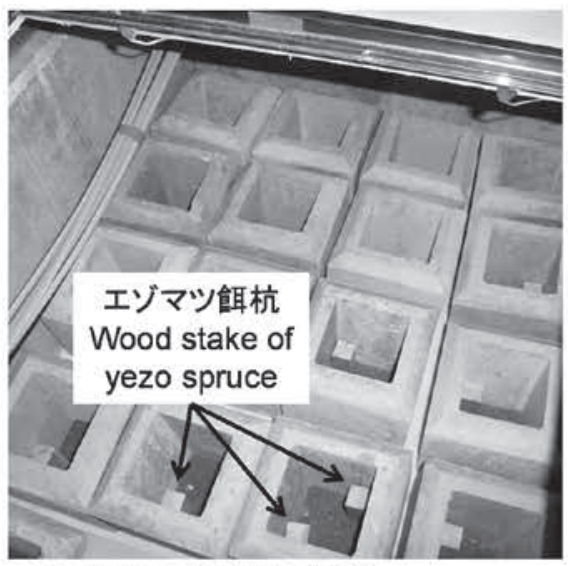

(c) 49基の会所枡の設置

Forty-nine concrete enclosures

図 2 実験住宅の床下でのコンクリート製会所枡を用いた貫通阻止性能試験

Fig. 2 Penetration test using concrete enclosure under the floor of experiment house

つて，シロアリの活性が高い環境下で，長期的な 貫通阻止性能試験をする必要がある。本試験では, エコ住宅実験棟床下の土壤あらわし部分 $(1.5 \times$ $1.5 \mathrm{~m})$ に，あらかじめヤマトシロアリ営巣木を 埋設させ，定期的に試験区とその周囲での慨杭の 食害状況やコンクリート基礎の蟻道の構築等を観 察することで，シロアリの活性をモニタリングし た。本実験では，実験住宅の床下では各粒子材料 を敷設するために，実際の住宅の基礎コンクリー トを想定して，角部をもったコンクリート製会所 枅 (外寸 $200 \mathrm{~mm}$ 角, 内寸 $120 \mathrm{~mm}$ 角, 高さ $200 \mathrm{~mm}$ ) を使用した（図 $2(a)) 。$ 会所枡内側の土壤に長さ $100 \mathrm{~mm}$, 断面35mm 角のエゾマツ (Picea jezoensis Carr.) 慨杭を 2 本打ち込み土畩あらわし部分 に，シロアリの会所枡内への侵入を誘導した（図 2(b)）。なお，土畩あらわし部分に慨杭を打ち込 んだコンクリート製会所枅を49基設置し, 飭杭の 食害状況や蟻道の構築状況を定期的に観察した (困 $2(\mathrm{c})$ )。エゾマツ飭杭へのシロアリ食害あるい は餌杭表面への蟻道の構築が確認された会所枡は 試験可能であると判断し（図 $3(\mathrm{a})$ ), 飭杭の上面 が隠れる高さまで砂壌土を追加して敷き詰め, 上 述の実験室実験で選別した粒子材料および砂壤土 (コントロール)を任意の厚さ（30mm または $40 \mathrm{~mm}$ ) まで敷設し, さらに粒子層の上に慨とし てアカマツ片を設置した（図 $3(b)) 。$ 粒子材料敷 設後は, 定期的に会所柲を観察し, シロアリの貫 通の有無を評価した（図 $3(\mathrm{c})$ )。なお, 各粒子材 料によって試験体数（繰り返し数）は異なり（表 2 )，粒子材料を敷設してない会所枅について,

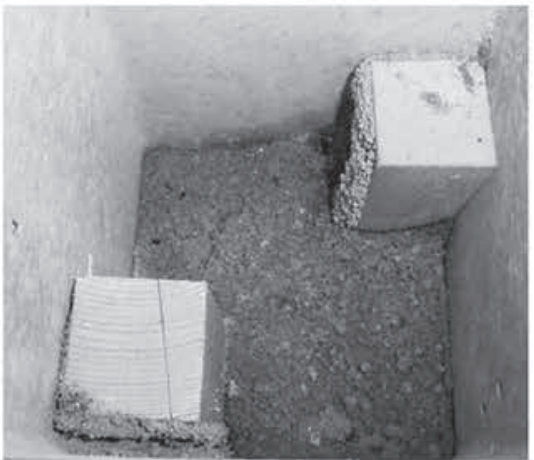

(a) 餌杭へのシロアリ食害と蟻道の構築 Termite infestation to wooden stakes and construction of termite tubes

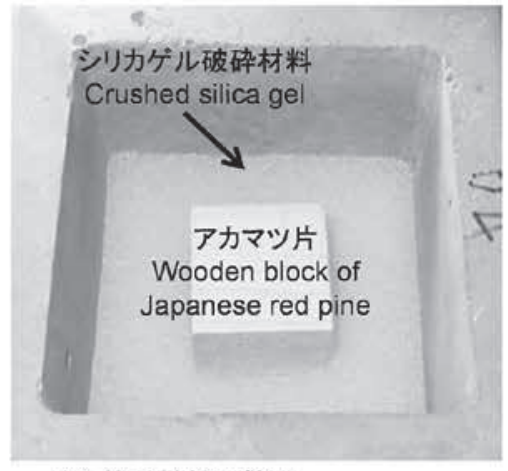

(b) 粒子材料の敷設

Setup of particulate material

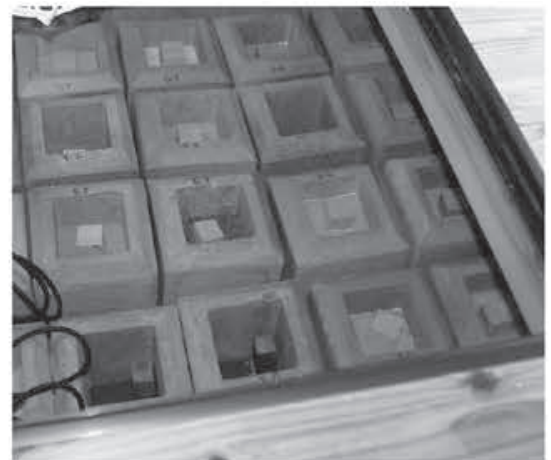

(c) シロアリの貫通行動のモニタリング Monitoring of termite penetration

図３コンクリート製会所枡内への粒子材料の敷設方法

Fig. 3 Setup of particulate material into concrete enclosure 
表 17 種類の粒子層への侵入距離

Table 1 Penetration length for layers of seven particulate materials

\begin{tabular}{|c|c|c|c|c|c|c|}
\hline \multirow{2}{*}{$\begin{array}{c}\text { 粒子材料 } \\
\text { Particulate material }\end{array}$} & \multirow{2}{*}{$\begin{array}{c}\text { 粒子径 }(\mathrm{mm}) \\
\text { Particle size }(\mathrm{mm})\end{array}$} & \multirow{2}{*}{$\begin{array}{l}\text { 粒子層厚さ }(\mathrm{mm}) \\
\text { Layer thickness }(\mathrm{mm})\end{array}$} & \multicolumn{3}{|c|}{$\begin{array}{c}\text { 侵入距離（mm） } \\
\text { Penetration length (mm) }\end{array}$} & \multirow{2}{*}{$\begin{array}{c}\text { 貫通試験体数 } \\
\text { Numbers of sample } \\
\text { passed through }\end{array}$} \\
\hline & & & 1 & 2 & 3 & \\
\hline $\begin{array}{c}\text { 石粉造粒材料 } \\
\text { Pelletized stone powder }\end{array}$ & $2.00 \sim 3.35$ & 30 & 10 & 2 & 5 & 0 \\
\hline $\begin{array}{l}\text { ゼオライト造粒材料 } \\
\text { Pelletized zeolite }\end{array}$ & $1.40 \sim 2.36$ & 40 & 7 & 9 & 10 & 0 \\
\hline $\begin{array}{l}\text { ゼオライト破砕材料 } \\
\text { Crushed zeolite }\end{array}$ & $1.40 \sim 2.80$ & 40 & 12 & 5 & 15 & 0 \\
\hline $\begin{array}{l}\text { カルサイト } \\
\text { Calcite }\end{array}$ & $1.40 \sim 2.80$ & 40 & 4 & 4 & 5 & 0 \\
\hline $\begin{array}{l}\text { シリカゲル破砕材料 } \\
\text { Crushed silica gel }\end{array}$ & $1.40 \sim 2.80$ & 30 & 2 & 0 & 5 & 0 \\
\hline $\begin{array}{l}\text { シリカゲルビーズ } \\
\text { Silica gel beads }\end{array}$ & $1.40 \sim 2.80$ & 30 & 5 & 5 & 0 & 0 \\
\hline $\begin{array}{l}\text { ガラスビーズ } \\
\text { Glass beads }\end{array}$ & $1.70 \sim 2.36$ & 30 & 0 & 0 & 3 & 0 \\
\hline $\begin{array}{l}\text { 砂袞土（コントロール） } \\
\text { Sandy loam (control) }\end{array}$ & $<1.00$ & 40 & 40 & 40 & 40 & 3 \\
\hline
\end{tabular}

食害の激しいエゾマツ飭杭は, 新しいエゾマツ慨 杭に交換し,シロアリ活性の維持を図った。

\section{3. 結果と考察}

\section{1 実験室における粒子材料選別試験}

表 1 は, 各粒子材料（繰り返し 3 回）に対して, 試験開始から 3 週間後に㧍けるイエシロアリの粒 子層への侵入距離を示す。コントロールとして用 いた層厚さ $40 \mathrm{~mm}$ の砂壤土は, 全て 1 日以内に貫 通された（侵入距離 $40 \mathrm{~mm}$ )。また， 7 種類の粒 子層については, 最大 $15 \mathrm{~mm}$ の侵入距離ではあっ たものの，全ての粒子層がシロアリに対して貫通 を阻止した。このことは, 筆者らの粒子の形状と 表面性状に関する研究10)により，シロアリの貫通 阻止に有効な粒子径を決定することが可能である ことを支持する結果となった。したがって，実験 住宅の床下でのシロアリ貫通阻止性能試験には, これら 7 種類の粒子材料を，それぞれ実験室実験 で使用した粒子径と粒子層厚さの条件で使用する こととした。

\section{2 実験住宅の床下におけるヤマトシロアリ貫 通阻止性能試験}

表 2 は, 粒子材料を会所枅内へ敷設してから 7 年経過後の貫通阻止性能試験の結果を示す。コン トロールとして砂壤土を敷設した会所柫 3 基は全
て 1 年以内にシロアリによって貫通されたこと， また粒子材料を敷設していない会所枅も全てで慨 杭への食害が定期的に観察されたことから，会所 妌を設置した床下土畩中でのシロアリの活性は, 試験期間を通して高かったと考えられる。7 年間 を通して, シロアリの貫通が確認された粒子材料 は, 石粉造粒材料が 3 試験体中 1 試験体（4年目 に貫通を確認), シリカゲルビーズが 5 試験体中 1 試験体（7 年目に貫通を確認），およびガラス ビーズが 3 試験体中 2 試験体（5 年目と 7 年目に 貫通を確認) であった。このことから 1 年のうち シロアリの活性の高い期間は, 常時シロアリが粒 子層に対して貫通行動をしていたと推察される が，貫通された 4 試験体を除く19試験体について はヤマトシロアリの貫通を阻止した。すなわち， ゼオライト造粒材料, ゼオライト破砕材料, カル サイト, シリカゲル破砕材料の 4 種類の粒子材料 にはシロアリに対して貫通阻止性能を有すること がわかった。

貫通された 4 試験体（3 種類の粒子材料）の貫 通部分を観察した結果，いずれの試験体も粒子敷 設領域の角部への蟻道構築が確認され, そこから 蟻道をのばし中央部へ設置したアカマッ片への食 害が観察された（図 4 (上))。そこで, 会所枡 23 基の全ての粒子材料を取り除き, シロアリの貫通 
表2 7 年間における各粒子材料の貫通阻止性能試験結果

Table 2 Result of penetration test of particulate materials for seven years

\begin{tabular}{|c|c|c|c|c|c|}
\hline \multirow{2}{*}{$\begin{array}{c}\text { 粒子材料 } \\
\text { Particulate material } \\
\text { 石粉造粒材料 } \\
\text { Pelletized stone powder }\end{array}$} & \multirow{2}{*}{$\begin{array}{c}\text { 粒子径 }(\mathrm{mm}) \\
\text { Particle size }(\mathrm{mm}) \\
2.00 \sim 3.35\end{array}$} & \multirow{2}{*}{$\begin{array}{c}\begin{array}{c}\text { 粒子層厚さ（mm） } \\
\text { Layer thickness（mm） }\end{array} \\
30\end{array}$} & \multirow{2}{*}{$\begin{array}{c}\begin{array}{c}\text { 試験体総数 } \\
\text { Total numbers } \\
\text { of sample }\end{array} \\
3\end{array}$} & \multicolumn{2}{|c|}{$\begin{array}{c}\text { 貫通試験体数 } \\
\text { Numbers of sample } \\
\text { passed through }\end{array}$} \\
\hline & & & & 1 & (A) \\
\hline $\begin{array}{c}\text { ゼオライト造粒材料 } \\
\text { Pelletized zeolite }\end{array}$ & $1.40 \sim 2.36$ & 40 & 5 & 0 & \\
\hline $\begin{array}{c}\text { ゼオライト破砕材料 } \\
\text { Crushed zeolite }\end{array}$ & $1.40 \sim 2.80$ & 40 & 2 & 0 & \\
\hline $\begin{array}{c}\text { カルサイト } \\
\text { Calcite }\end{array}$ & $1.40 \sim 2.80$ & 40 & 3 & 0 & \\
\hline $\begin{array}{l}\text { シリカゲル破砕材料 } \\
\text { Crushed silica gel }\end{array}$ & $1.40 \sim 2.80$ & 30 & 2 & 0 & \\
\hline $\begin{array}{l}\text { シリカゲルビーズ } \\
\text { Silica gel beads }\end{array}$ & $1.40 \sim 2.80$ & 30 & 5 & 1 & (B) \\
\hline $\begin{array}{l}\text { ガラスビーズ } \\
\text { Glass beads }\end{array}$ & $1.70 \sim 2.36$ & 30 & 3 & 2 & (C) \\
\hline $\begin{array}{c}\text { 砂壤土（コントロール） } \\
\text { Sandy loam (control) }\end{array}$ & $<1.00$ & 40 & 3 & 3 & \\
\hline
\end{tabular}
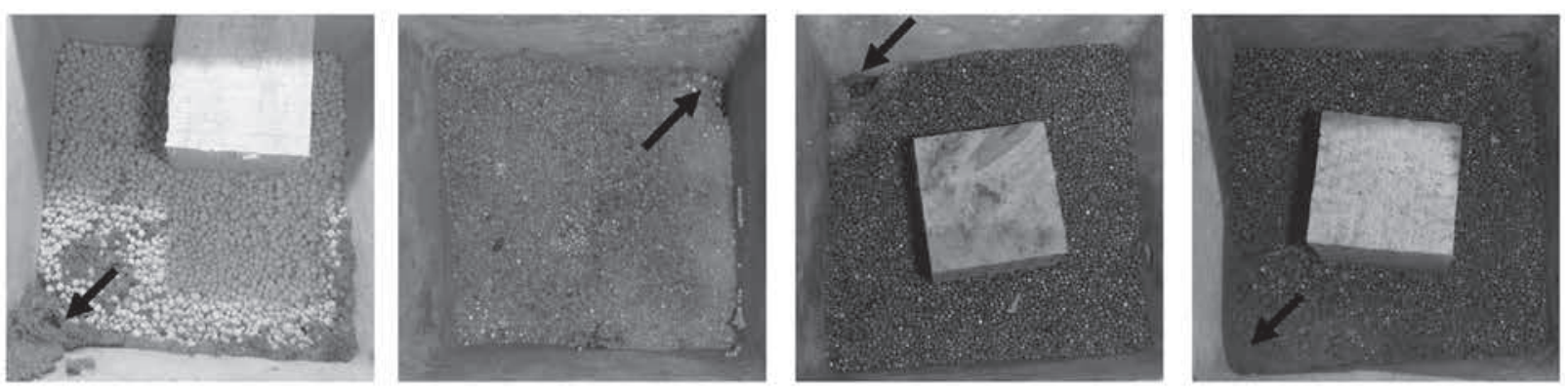

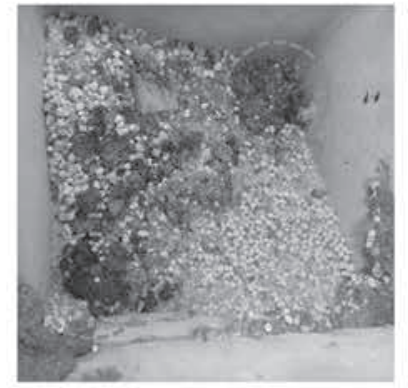

石粉造粒材料(A)

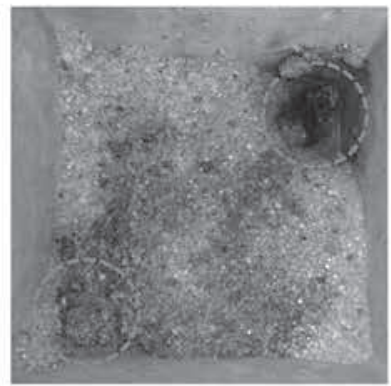

シリカゲルビーズ(B) Silica gel beads (B)

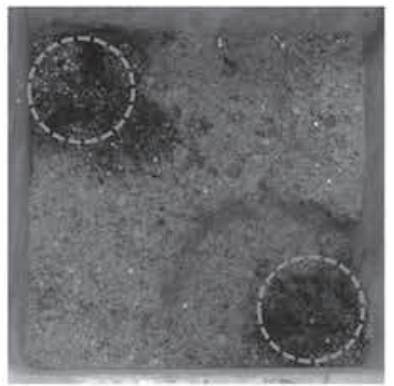

ガラスビーズ (C) Glass beads (C)

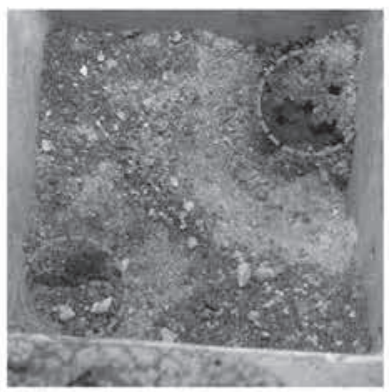

ガラスビーズ (C) Glass beads (C)

Pelletized stone powder $(A)$

図 4 粒子層コーナー部の貫通（上）とその直下の餌杭の食害状況（下）

Fig. 4 Corners of particle layer passed through by termite (upper) and the damage of wooden stakes underneath (bottom)

注：図中の矢印は, シロアリに貫通された部分を示す。 $(\mathrm{A})$ ～(C) は表 2 を参照。

Note : The arrows show the positions passed through by termites. (A) - (C) refer to table 2 . 
経路の観察を行った結果，シロアリに貫通された 4 つの会所妌のみ角部の飭杭が食害を受け空洞化 し，それ以外の会所妌では空洞化は確認されなか った。砂壤土（コントロール）を除いて貫通が確 認された 4 つの試験体は, 蟻道構築と貫通が確認 された角部と粒子敷設前の誘導用のエゾマツ餌杭 の打ち込み位置が一致した（図4 (下))。シロア リに貫通された会所妌は全て角部の慨杭が食害を 受け空洞化し，粒子がその空洞へ流れ込むことに よって，粒子敷設領域の角部の粒子層が陥没し， シロアリが貫通可能な隙間が発生したと考えられ る(図 5 )。貫通が確認された 3 種類の粒子材料 はいずれも粒子どうしが密に詰まって隙間が小さ くなる球形に近い形状であったことから，容易に 空洞へ流れ込んだと推測される。したがって，本 研究でシロアリに貫通された粒子材料は，実験室 実験により粒子そのものは貫通阻止性能を有する と評価されたが，会所栘を用いた長期間の試験で は, 誘導用の餌杭の消費による空洞化が原因で貫 通阻止性能が発揮されなかったと考えられる。貫 通阻止性能を有する粒子材料を新築あるいは既築 住宅へ施工するためには，効果的な使用に際して は粒子材料の流出が生じない仕様に合わせた施工 方法の検討が必要である。また，今回の会所栘を 用いた床下に打ける貫通阻止性能試験では, 粒子 を敷設する前に，そのまま砂畩土を慨杭の上面が 隠れる高さまで敷き詰めるのではなく，飭杭を横 に寝かせて設置することや慨杭をチップ状の木片 に交換する，またはJWPAS-TS-(2)（2011）の 5 . 野外試験 ${ }^{12)}$ に倣い慨木を取り払うことによって, 長期間の試験においても角部に隙間ができないよ う試験方法を改良する必要がある。

\section{4. まとめ}

本研究では, 実験住宅床下に営巣させたヤマト シロアリに対して, 床下土畩面へ 7 種類の粒子材 料を敷設し, 7 年間の物理バリアとしての貫通阻 止性能を評価した。実験室実験で貫通阻止性能が 認められた粒子材料のうち, ゼオライト造粒材料, ゼオライト破砕材料, カルサイト, シリカゲル破 砕材料は会所枅を用いた貫通阻止性能でもヤマト シロアリの貫通を阻止したが，石粉造粒材料， シ リカゲルビーズ，ガラスビーズでは貫通された試

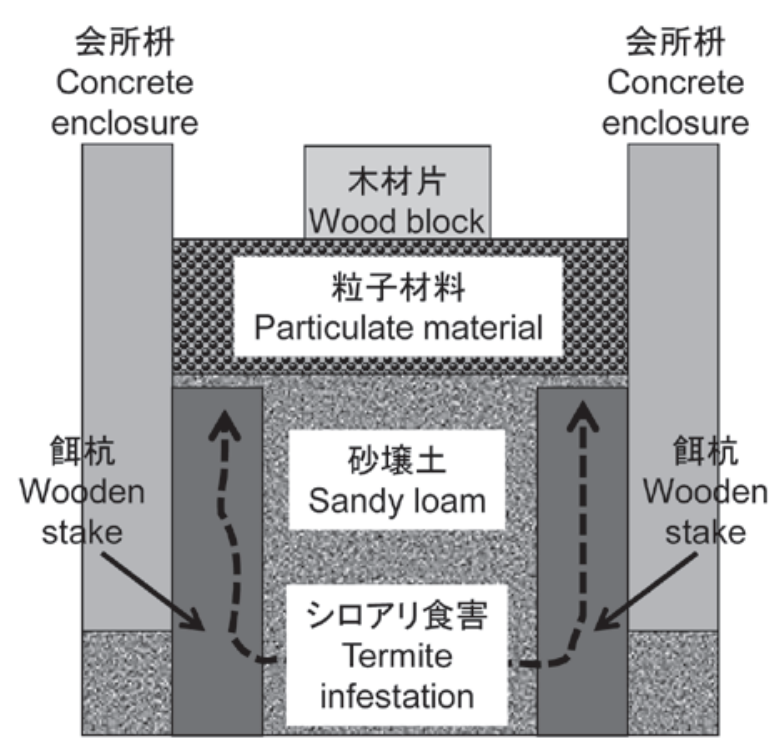

(a) 餌杭へのシロアリ食害 Termite infestation to wooden stake

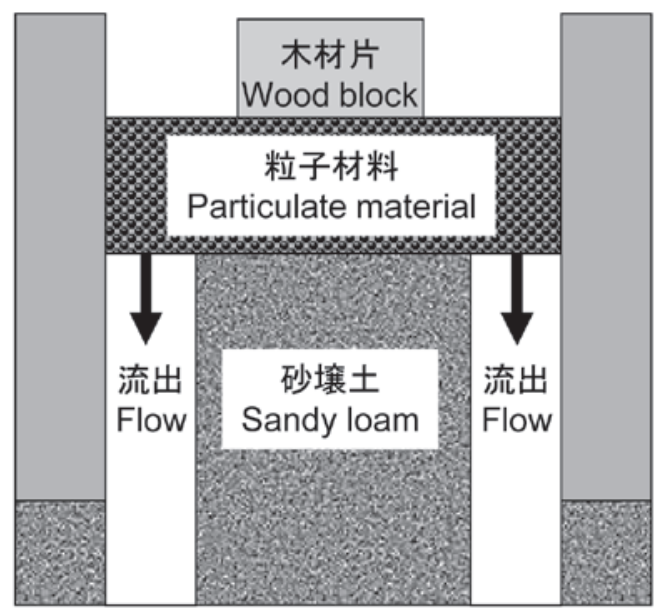

(b) 餌杭消費後の空洞への粒子材料の流出 Flow of particulate material into to cavity after severe consumption of wooden stake

図 5 ヤマトシロアリによる粒子層の貫通機構

Fig. 5 Mechanism of passing through the particle layer by $R$. speratus

験体があった。貫通された試験体は全て, 粒子敷 設領域の角部で粒子層直下のエゾマツ餌杭が消費 され，空洞化したことによって，粒子が空洞へ流 れ込み，結果として粒子層が陥没し，貫通された ことが観察された。したがって, 本研究で使用し た粒子材料は, 実験室実験の結果より物理バリア としてのシロアリ貫通阻止性能を有すると考えら れるが，住宅の床下への施工においては長期性能 を十分に発揮する方法を検討する必要がある。ま た，床下で会所栘を用いた性能試験方法について 
は，粒子層が陥没しない方法へ改良することが必 要である。

\section{謝辞}

本研究の一部は, 「京都大学生存圈研究所木質 材料実験棟平成20～28年度共同利用研究（研究代 表者：筞瀬佳之)」により実施した。ここに記し て謝意を表する。

\section{引用文献}

1 ) Tamashiro, M., Yates, J. R., Yamamoto, R. T. and Ebesu, R. H. : Tunneling behavior of the formosan subterranean termites and basalt barriers, Sociobiology, 19 (1), 163-170 (1991).

2 ) French, J. R. J. and Ahmed, B. : Termite physical barriers : Is retrofitting with Granit$\operatorname{gard}^{\mathrm{TM}}$ an option?, IRG Document IRG/WP9340011 (1993).

3 ) Ebeling, W. and Pence, R. J. : Relation of particle size to the penetration of subterranean termites through barriers of sand or cinders, Journal of Economic Entomology, 50 (5), 690-692 (1957).

4 ) Su, N.-Y., Scheffrahn, R. H. and Ban P. M. : Uniform size particle barriers : a physical exclusion device against subterranean termites (Isoptera : Rhinotermitidae), Journal of Economic Entomology, 84 (3), 912-916 (1991).

5 ) French, J. R. J. : The case for non-chemical termite barriers in termite control, IRG Document IRG/WP1381 (1989).

6) Pallaske, M. and Igarashi, A.: Glass splinders as physical termite barriers: Optimized material properties in use with and without insecticidal pretreatment minimizes environmental contaminations, IRG Document IRG/WP1476 (1991).

7 ) Su, N.-Y., Scheffrahn, R. H. and Ban P. M. : Penetration of sized-particle barriers by field populations of subterranean termites (Isoptera: Rhinotermitidae), Journal of Economic Entomology, 85 (6), 2275-2278 (1992).

8 ) Sornnuwat, Y., Vongkaluang, C., Yoshimura, Tsunoda, T., K. and Takahashi, M. : Tunneling of subterranean termites, Coptotermes gestroi Wasmann and Coptotermes formosanus Shiraki, into gravel physical barriers, Japanese Journal of Environmental Entomology and Zoology, 7 (3), 3-19 (1995).

9 ) Yanase, Y., Shibata, M., Fujii, Y., Okumura, S., Iwamoto, K., Nogiwa, T., Yoshimura, T. and Imamura, Y. : Feasibility of termite control using crushed cement-stabilized sludge (Polynite) as a physical barrier and acoustic emission (AE) monitoring, IRG Document IRG/WP 00-10381 (2000).

10）筞瀬佳之, 藤井義久, 奥村正悟, 吉村剛, 今 村祐嗣, 石田充克, 川口浩寿, 奥村敏信：種々 の粒子材料のシロアリ物理バリアへの適用 一粒子径，粒子形状掞よび表面性状がシロアリ の貫通行動に与える影響 一, 材料, 54 (4), 387-391 (2005).

11）筞瀬佳之，上谷幸治郎，藤井義久，奥村正悟： ゼオライト造粒材料の吸放湿性とシロアリ貫通 阻止性能, 材料, 58 (4)，304-309 (2009).

12）社日本木材保存協会編：“社団法人日本木材 保存協会規格集 (2011版)”, 2011, pp47-54.

(2018.3.5 受付) (2019.4.11受理) 